\title{
DIMETHOXYFLAVONE ISOLATED FROM THE STEM BARK OF STEREOSPERMUM KUNTHIANUM POSSESSES ANTIDIARRHOEAL ACTIVITY IN RODENTS
}

\author{
Ching, F. P. ${ }^{1 *}$, Otokiti, I. O. $^{2}$ and Egert-omoneukanrin, B. ${ }^{2}$ \\ ${ }^{1 *}$ Department of Pharmacology, Faculty of Basic Medical Sciences, College of Health Sciences, Niger \\ Delta University, Wilberforce Island, Yenagoa, Nigeria, ${ }^{2}$ Department of Pharmacology \& Toxicology, \\ Faculty of Pharmacy, University of Benin, Benin City, Nigeria \\ *fidelchingp@gmail.com, fidelching@yahoo.ca
}

\begin{abstract}
This study was undertaken to evaluate the antidiarrhoeal activity of 3, 7, $4^{\prime}$-trihydroxy-3'-(8'/'-acetoxy-7/'-methyloctyl)-5, 6-dimethoxyflavone, a flavonoid isolated from the stem bark of Stereospermum kunthianum. The antidiarrhoeal activity was evaluated using rodent models with diarrhoea. The normal intestinal transit, castor oil-induced intestinal transit and castor oilinduced diarrhoea tests in mice as well as castor oil-induced intestinal fluid accumulation in rats were employed in the study. The animals were pretreated with distilled water (10 ml/kg for mice, $5 \mathrm{ml} / \mathrm{kg}$ for rats), dimethoxyflavone (25 mg/kg or $50 \mathrm{mg} / \mathrm{kg}$ ), morphine (10 mg/kg), or indomethacin $(10 \mathrm{mg} / \mathrm{kg}$ ) before induction of diarrhoea with castor oil $(0.2 \mathrm{ml}$ for mice and $2 \mathrm{ml}$ for rats). Dimethoxyflavone dose dependently and significantly reduced $(P<0.05)$ castor oil-induced intestinal motility. Its antimotility effect at the dose of $50 \mathrm{mg} / \mathrm{kg}$ was higher compared to that of morphine (10 mg/kg). Dimethoxyflavone (25 mg/kg and $50 \mathrm{mg} / \mathrm{kg})$ caused a delay in the onset of diarrhoea reduction in the number and weight of wet stools and total stools in mice with castor oilinduced diarrhoea compared to the distilled water treated mice. Treatment with dimethoxyflavone ( $25 \mathrm{mg} / \mathrm{kg}$ or $50 \mathrm{mg} / \mathrm{kg}$ ) did not produce any remarkable effect on castor oil-induced intestinal fluid accumulation in rats and normal intestinal transit in mice. The results indicate that dimethoxyflavone possesses antidiarrhoeal activity due to its intestinal antimotility effect and inhibition of other diarrhoeal pathophysiological processes. In conclusion, dimethoxyflavone reduced the frequency and severity of diarrhoea in the diarrhoeal models studied.
\end{abstract}

Keywords: Dimethoxyflavone, Stereospermum kunthianum, flavonoid, antidiarrhoeal activity

\section{Introduction}

Diarrhoea is the leading cause of death in childhood and the frail elderly (Kosec et al., 2003). Gastrointestinal alterations accompanied with diarrhoea have their major impact in the developing world (WHO, 2009). In the developed world, despite improvements in public health and economic wealth, the incidence of diarrhoea is not completely wiped out and continues to be an important clinical problem (WHO, 2009).

Although a number of therapeutic agents have been developed for the management of diarrhoea (Keith and John, 2012), there is a need for the continuous search for antidiarrhoeal agents. The rural dwellers in most parts of the developing world rely on their indigenous medicine, usually medicinal plants for the management of diarrhoea. Stereospermum kunthianum, a woody shrub of the Sudano-Guinea savannah regions of Africa and Asia, is used in the management of diarrhoea and dysentery in Nigeria and other West African countries (Von Maydell, 1986; Gill, 1992). Its aqueous stem bark extract have been reported to possess antidiarrhoeal activity (Ching et al., 2008).

Chromatographic fractions of the stem bark extract have also demonstrated antidiarrhoeal activity (Ching et al., 2009). We previously isolated, characterised and elucidated some bioactive constituents from Stereospermum kunthianum stem bark (Falodun et al., 2009), with analgesic and antiinflammatory activities (Ching et al., 2009). In continuation with our efforts to identify the bioactive compounds that could be responsible for the reported activities from Stereospermum kunthianum stem bark, we isolated, characterised and elucidated an alklyated flavonoid (3,7,4'-trihydroxy-3'-(8' ${ }^{\prime \prime}$-acetoxy-7'-methyloctyl)-5,6dimethoxyflavone (Ching and Falodun, 2011). In the present study, we report the antidiarrhoeal activity of dimethoxyflavone in rodents.

\section{Materials and Methods Dimethoxyflavone}

Dimethoxyflavone, a flavonoid previously isolated, characterised and elucidated (Ching and Falodun, 2011), was a yellowish powder. 


\section{Animals}

Twenty Wistar rats $(140-150$ g) and sixty Swiss mice (20 - 25 g) of either sex were used in the study. The animals which were maintained under standard laboratory conditions and natural 12 hours light and dark cycles had free access to standard chow (Bendel Feeds Plc. Ewu, Nigeria) and drinking water. The experimental protocols used in the study had the approval of the Animal Ethics Committee of the University of Benin, Benin City, Nigeria. Animals were handled according to the protocol outlined in "Principles of Laboratory Animal Care" (NIH, 1985).

\section{Drugs and chemicals}

The reference drugs - morphine and indomethacin - used in the study were products of the British Drug House (BDH), London. Olive oil, castor oil and activated charcoal used were products of Andalucía, Spain, and were purchased from the Supreme Pharmacy, Benin City, Edo State, Nigeria.

\section{Effect of dimethoxyflavone on the normal intestinal transit in mice}

The effect of dimethoxyflavone on normal intestinal propulsion in mice was evaluated using the charcoal meal method (Aye-Than et al., 1989). Overnight fasted mice of either sex were randomly allocated into four groups of 5 animals each. Group I (negative control) received distilled water $(10 \mathrm{ml} / \mathrm{kg}$, p.o.), Group II received dimethoxyflavone (25 mg/kg, p.o), Group III received dimethoxyflavone (50 mg/kg, p.o), and Group IV (positive control) received morphine (10 mg/kg, Sc). Thirty minutes later, the animals were each administered a freshly prepared standard charcoal test meal $(0.2 \mathrm{ml}$ of a $10 \%$ activated charcoal suspension in 5\% gum acacia) by oral route. After 30 minutes, the animals were sacrificed by excess chloroform inhalation. The small intestine was isolated and the distance traversed by the charcoal meal from the pylorus to the ileocaecal junction was measured. The length of the entire small intestine was also measured. The peristaltic index for each mouse was then expressed as a percentage of the distance traversed by the charcoal meal relative to the total length of the small intestine.

\section{Effect of dimethoxyflavone on castor oil-induced intestinal transit in mice}

The method of Aye-Than et al. (1989) was used to evaluate the effect of dimethoxyflavone on castor oil-induced intestinal transit in mice. Thirty minutes before oral administration of castor oil ( $0.2 \mathrm{ml}$ per mouse), four groups of mice (5 per group) were administered with distilled water (10 ml/kg, p.o) (negative control), dimethoxyflavone (25 mg/kg and $50 \mathrm{mg} / \mathrm{kg}$, p.o), and morphine (reference drug, $10 \mathrm{mg} / \mathrm{kg}$, Sc) respectively. Thirty minutes, later a standard charcoal meal $(0.2 \mathrm{ml}$ of a $10 \%$ activated charcoal suspension in 5\% gum acacia) was administered to each mouse by the oral route. After thirty minutes, the animals were sacrificed by excess chloroform inhalation and the small intestine was isolated. The distance traversed by the charcoal meal from the pylorus to the ileocaecal junction was measured. The length of the entire small intestine was also measured. The peristaltic index for each mouse was then expressed as a percentage of the distance traversed by the charcoal meal relative to the total length of the small intestine.

\section{Effect of dimethoxyflavone on castor oil-induced intestinal fluid accumulation in rats}

The method of Robert et al. (1976) was used to evaluate the effect of dimethoxyflavone on castor oil-induced intestinal fluid accumulation in rats. The animals were randomly allocated into four groups of 5 animals each. Group I (negative control) received distilled water ( $5 \mathrm{ml} / \mathrm{kg}$, p.o), Groups II and III received dimethoxyflavone (25 mg/kg and $50 \mathrm{mg} / \mathrm{kg}$, p.o respectively) and Group IV received indomethacin suspended in olive oil $(10 \mathrm{mg} / \mathrm{kg})$ orally. One hour later, each animal received $2 \mathrm{mls}$ of castor oil by oral route. After One hour, the animals were sacrificed by excess chloroform inhalation. The entire small intestine was isolated after ligation at the pyloric end and the ileocaecal junction respectively. The intestinal contents were expelled into a graduated measuring cylinder and the volume determined.

\section{Effect of dimethoxyflavone on castor oil-induced diarrhoea in mice}

The method of Izzo et al. (1989) was used to evaluate the effect of dimethoxyflavone on castor oil-induced diarrhoea in mice. The animals were randomly allocated into four groups of 5 animals each. Group I (control group) received distilled water $(10 \mathrm{ml} / \mathrm{kg}, \mathrm{p} . \mathrm{o})$, groups II and III received dimethoxyflavone $(25 \mathrm{mg} / \mathrm{kg}$ and $50 \mathrm{mg} / \mathrm{kg}$, p.o respectively) and group IV received morphine $(10 \mathrm{mg} / \mathrm{kg}, \mathrm{Sc})$. Thirty minutes later, $0.2 \mathrm{ml}$ of castor oil was orally administered to each mouse. Each mouse was placed under a transparent funnel, the floor of which was lined with weighed filter paper (Whatmann No. 1) and was observed for 4 hours. The parametres observed included the onset of diarrhoea stool (first wet stool that leaves a halo on the filter paper), number of wet stools, weight of wet stools and total weight of faecal output. Calculations were made for the delay diarrhoea onset and purging index by comparison with the control group.

\section{Statistical analysis}

Results were analysed using the Student t-test, expressed as mean \pm S.E.M and considered significant when $\mathrm{P}<0.05$. 


\section{Results}

Table 1 represents the results of the effect of dimethoxyflavone on normal intestinal transit in mice. In the negative control group (distilled water-treated animals), the peristaltic index was $51.00 \pm 2.20$. Dimethoxyflavone at the doses of $25 \mathrm{mg} / \mathrm{kg}$ and $50 \mathrm{mg} / \mathrm{kg}$ caused peristaltic indices of $51.65 \pm 4.35$ and $49.43 \pm 6.40$, respectively. These were not significantly different $(P>0.05)$ from the peristaltic index of the negative control group. However, morphine $(10 \mathrm{mg} / \mathrm{kg})$ produced a peristaltic index of $18.72 \pm 4.50$ which was significantly different $((P<0.05)$ from the negative control group (Table 1$)$.

Table 1: The effect of dimethoxyflavone on normal intestinal transit in mice

\begin{tabular}{lcccc}
\hline Group & Treatment & CML (cm) & IL (cm) & $\begin{array}{c}\text { Peristaltic index } \\
\text { (\%) }\end{array}$ \\
\hline I & Distilled water $(10 \mathrm{ml} / \mathrm{kg})$ & $35.9 \pm 1.26$ & $70.6 \pm 2.20$ & $51.0 \pm 2.20$ \\
II & Dimethoxyflavone $(25 \mathrm{mg} / \mathrm{kg})$ & $32.8 \pm 2.70$ & $63.7 \pm 1.80$ & $51.65 \pm 4.34$ \\
III & Dimethoxyflavone $(50 \mathrm{mg} / \mathrm{kg})$ & $31.0 \pm 1.79$ & $64.4 \pm 4.30$ & $49.4 \pm 6.40$ \\
IV & Morphine $(10 \mathrm{mg} / \mathrm{kg})$ & $12.3 \pm 2.08$ & $66.4 \pm 1.60$ & $18.7 \pm 4.50^{\mathrm{a}}$ \\
\hline
\end{tabular}

Values are mean \pm S.E.M of five experiments, CML $=$ Charcoal meal length, IL $=$ Intestinal length. ${ }^{\mathrm{a}} \mathrm{P}<0.05$ significantly different from the distilled water-treated mice, student's t-test.

Table 2: Effect of dimethoxyflavone on castor oil-induced intestinal transit in mice

\begin{tabular}{llcccc}
\hline Group & \multicolumn{1}{c}{ Treatment } & CML (cm) & IL (cm) & $\begin{array}{l}\text { Peristaltic } \\
\text { index (\%) }\end{array}$ & $\begin{array}{l}\text { Percentage } \\
\text { inhibition }\end{array}$ \\
\hline I & Distilled water $(10 \mathrm{ml} / \mathrm{kg})$ & $24.32 \pm 2.40$ & $65.5 \pm 2.60$ & $37.6 \pm 3.62$ & - \\
II & Dimethoxyflavone $(25 \mathrm{mg} / \mathrm{kg})$ & $20.6 \pm 3.30$ & $69.5 \pm 2.90$ & $29.8 \pm 4.82$ & 20.6 \\
III & Dimethoxyflavone $(50 \mathrm{mg} / \mathrm{kg})$ & $16.1 \pm 2.90$ & $71.5 \pm 2.80$ & $22.2 \pm 3.12^{\mathrm{a}}$ & 40.8 \\
IV & Morphine (10 mg/kg) & $14.8 \pm 2.90$ & $61.9 \pm 1.84$ & $23.8 \pm 4.93^{\mathrm{a}}$ & 36.5 \\
\hline
\end{tabular}

Values are mean \pm S.E.M of five experiments. CML $=$ Charcoal meal length, IL $=$ Intestinal length. ${ }^{\mathrm{a}} P<0.05$ significantly different from the distilled water-treated mice, student's t-test.

Table 3: The effect of dimethoxyflavone on castor oil-induced intestinal fluid accumulation in rats

\begin{tabular}{ccc}
\hline Group & Treatment & $\begin{array}{c}\text { Volume of intestinal } \\
\text { content }(\mathbf{m l})\end{array}$ \\
\hline I & Distilled water $(10 \mathrm{ml} / \mathrm{kg})$ & $1.28 \pm 0,23$ \\
II & Dimethoxyflavone $(25 \mathrm{mg} / \mathrm{kg})$ & $1.52 \pm 0.24$ \\
III & Dimethoxyflavone $(50 \mathrm{mg} / \mathrm{kg})$ & $1.71 \pm 0.29$ \\
IV & Morphine $(10 \mathrm{mg} / \mathrm{kg})$ & $1.16 \pm 0.26$ \\
\hline \multicolumn{2}{l}{ Values }
\end{tabular}

Values are mean \pm SEM of five experiments

Table 4: Effect of dimethoxyflavone on castor oil-induced diarrhoea in mice

\begin{tabular}{lccccc}
\hline Treatment & $\begin{array}{c}\text { Onset of diarrhoea } \\
\text { (min) }\end{array}$ & $\begin{array}{c}\text { Number of wet } \\
\text { stools }\end{array}$ & $\begin{array}{c}\text { Total number } \\
\text { of stools }\end{array}$ & $\begin{array}{c}\text { Total weight of } \\
\text { wet stools (g) }\end{array}$ & $\begin{array}{c}\text { Total weight } \\
\text { of stools (g) }\end{array}$ \\
\hline $\begin{array}{l}\text { Distilled water } \\
(10 \mathrm{ml} / \mathrm{kg})\end{array}$ & $33.8 \pm 3.99$ & $7.2 \pm 0.96$ & $11.6 \pm 1.56$ & $0.71 \pm 0.22$ & $0.77 \pm 0.11$ \\
$\begin{array}{l}\text { Dimethoxyflavone } \\
(25 \mathrm{mg} / \mathrm{kg})\end{array}$ & $86.8 \pm 24.60$ & $5.0 \pm 1.85$ & $11.2 \pm 1.77$ & $0.39 \pm 0.19^{\mathrm{a}}$ & $0.64 \pm 0.26^{\mathrm{a}}$ \\
$\begin{array}{l}\text { Dimethoxyflavone } \\
\text { (50 mg/kg) }\end{array}$ & $90.5 \pm 19.80$ & $4.5 \pm 2.25$ & $9.25 \pm 2.09$ & $0.26 \pm 0.07^{\mathrm{a}}$ & $0.69 \pm 0.17^{\mathrm{a}}$ \\
$\begin{array}{l}\text { Morphine } \\
(10 \mathrm{mg} / \mathrm{k})\end{array}$ & $0.00 \pm 0.00$ & $0.00 \pm 0.00$ & $0.00 \pm 0.00$ & $0.00 \pm 0.00$ & $0.00 \pm 0.00$
\end{tabular}

$(10 \mathrm{mg} / \mathrm{kg})$

Values are mean \pm S.E.M of five experiments. CML $=$ Charcoal meal length, IL $=$ Intestinal length. ${ }^{\mathrm{a}} P<0.05$ significantly different from the distilled water-treated mice, student's t-test.

Table 2 shows the effect of the dimethoxyflavone on castor oil-induced intestinal transit in mice. The peristaltic index for distilled water-treated animals was $37.55 \pm 3.62$, while dimethoxyflavone $(25 \mathrm{mg} / \mathrm{kg}$ and $50 \mathrm{mg} / \mathrm{kg})$ had peristaltic indices of $37.55 \pm 3.62$ and $22.23 \pm 3.12$ respectively, with percentage inhibition of castor oil-induced intestinal motilities of 20.6 and 40.8 respectively. Morphine caused a peristaltic index of $23.84 \pm 4.93$ with percentage inhibition of castor oil-induced intestinal motility of 36.5 .

Table 3 shows the results of the effect of dimethoxyflavone on intestinal fluid accumulation in rats. Oral administration of castor oil to rats pretreated with distilled water $(5 \mathrm{ml} / \mathrm{kg})$ caused intestinal fluid volume of $1.28 \pm 0.23 \mathrm{ml}$. In the rats administered dimethoxyflavone (25 mg/kg and $50 \mathrm{mg} / \mathrm{kg}$, orally) one hour before castor oil, the intestinal fluid volumes were 1.52 
$\pm 0.24 \mathrm{ml}$ and $1.71 \pm 0.29 \mathrm{ml}$ respectively, which was not significantly different $(P>0.05)$ from that of distilled water-treated rats. In the rats pretreated with indomethacin $(10 \mathrm{mg} / \mathrm{kg})$, the intestinal fluid volume was $1.16 \pm 0.26 \mathrm{ml}$, which was also not significantly different $(P>0.05)$ from the distilled water-treated rats.

The results of the effect of dimethoxyflavone on castor oil-induced diarrhoea are presented in Table 4. Following castor oil administration, the mice pretreated with distilled water $(10 \mathrm{ml} / \mathrm{kg})$ produced diarrhoea with an onset of $33.8 \pm 3.99$ minutes. Dimethoxyflavone at the dose of $25 \mathrm{mg} / \mathrm{g}$ and $50 \mathrm{mg} / \mathrm{kg}$ administered to mice thirty minutes before the oral administration of castor oil caused a delay in the onset of diarrhoea (86.8 \pm 24.80 and $90.5 \pm 19.80$ minutes), a reduction in the number of wet stool (5.0 \pm 1.85 and $4.5 \pm 2.25)$, total weight of wet stool $(0.39 \pm 0.19$ and $0.26 \pm 0.07 \mathrm{~g})$, and total weight of stool $(0.64 \pm 0.26$ and $0.69 \pm 0.17 \mathrm{~g})$ respectively when compared to the distilled water-treated mice. The mice which received morphine $(10 \mathrm{mg} / \mathrm{kg}) \mathrm{did}$ not produce diarrhoea stool at all. There was a significant delay $(P<0.05)$ in the onset of diarrhoea and a significant reduction $(P<0.05)$ in the total weight of wet stools in the mice which received dimethoxyflavone at the dose of $50 \mathrm{mg} / \mathrm{kg}$. There was a significant delay $(P<0.05)$ in the onset of diarrhoea in the mice which received dimethoxyflavone $(25 \mathrm{mg} / \mathrm{kg})$.

\section{Discussion}

Diarrhoea is the passage of three or more loose or liquid stools per day or more frequent passage than is normal for an individual (WHO, 2009). Diarrhoea is an alteration in the normal bowel movement characterised by increased frequency of bowel sound and movement, wet stool, and abdominal pain (Guerrant et al., 2001). Clinically, it is used to describe increased liquidity of stool usually associated with increased stool weight and frequency. Diarrhoea is characterised by increased active luminal secretion and decreased reabsorption of water and electrolytes from the lumen. The resulting net secretion causes the increase in stool volume and weight. Decreased transit time and abnormal motor activities occur in patients with diarrhoea (Eugene, 1997). The inhibition of experimental diarrhoea and reduction in faecal output by a substance are the basis of the pharmacological evaluation of a potential anti-diarrhoeal agent (Akah et al., 1999).

The results of this study revealed that dimethoxyflavone isolated from the stem bark of Stereospermum Kunthianum possesses anti-diarrhoeal activity in animals with diarrhoea. Dimethoxyflavone produced no significant effect on the normal intestinal transit in mice. But in castor oil-induced intestinal transit in mice, dimethoxyflavone produced a dose-dependent decrease in distance traversed by the activated charcoal test meal, thus indicating possible antispasmodic activity. Also, dimethoxyflavone $(50 \mathrm{mg} / \mathrm{kg})$ produced a higher percentage inhibitory intestinal transit time effect than morphine. This may suggest that dimethoxyflavone at this dose may have more antispasmodic effect than morphine. This antispasmodic effect allows more time for water to be absorbed from faecal matter and results into better formed faecal materials. Dimethoxyflavone did not inhibit castor oil-induced intestinal fluid accumulation, thus suggesting that its antidiarrhoeal activity may not be related to antisecretory action. Indomethacin, the reference drug used in this study, is a non-steroidal anti-inflammatory drug which has also been found to cause delay in onset of castor oil-induced diarrhoea and inhibit intestinal fluid secretion (Awounters et al., 1978). The frequency and severity of castor oil-induced diarrhoea in mice were inhibited by dimethoxyflavone. The active component of castor oil, ricinoleic acid, induces permeability changes in mucosal fluid and electrolyte transport that results in a hyper-secretory response and diarrhoea (Rajabhau et al., 2011). Ricinoleic acid also produces irritation and inflammation of the intestinal mucosa, leading to release of prostaglandins, which stimulate motility and secretion. The antidiarrhoeal activity of dimethoxyflavone against castor oil-induced diarrhoea in mice may be attributed to an antielectrolyte permeability action. Dimethoxyflavone caused a delay in onset of diarrhoea and reduced the total number of stools, number of wet stools, and weight of wet stools with the highest effect observed at the $50 \mathrm{mg} / \mathrm{kg}$ body weight of dimethoxyflavone. These effects were however comparatively less than those produced by morphine. The antidiarrhoeal activity of flavonoids has been ascribed to their ability to inhibit intestinal motility and hydro-electrolytic secretions (Di Carlo et al., 1993; Di Carlo et al., 1999). In-vitro and in-vivo experiments have shown that flavonoids are able to inhibit the intestinal secretory response, induced by prostaglandins $\mathrm{E}_{2}$ (Venkatesan et al., 2005). Dimethoxyflavone isolated from the stem bark of Stereospermum kunthianum produced antimotility effect against castor oilinduced diarrhoea in mice.

In conclusion, the results of this study taken together indicate that dimethoxyflavone possesses antidiarrhoeal activity. Although the exact mechanism of its antidiarrhoeal activity could not be established in this study, the diarrhoeal models used in the study show that dimethoxyflavone has antimotility activity that contributes to its antidiarrhoeal activity.

\section{References}

1. Akah,,P.A., Aguwa, C.N., Agu, R.U. (1999). Studies on the antidiarrhoeal properties of Pentaclethra macrophylla leaf extracts. Phytother. Res. 13(4): 292 - 295.

2. $\quad$ Awounters, F., Niemegeers, C.J.E., Lenaerts, F.M., Janseen, P.A.J. (1978). Delay of castor oil diarrhea in rats: a new way to evaluate inhibition of prostaglandin biosynthesis. J. Pharm. Pharmacol. 30: 41-45

3. Aye-Than, J.V., Kukami, W., Tha, S.L. (1989). Antidiarrhoeal efficacy of some Burmese indigenous drug formulations in experimental diarrhoea test models. J. Crude drug Res. 27:195-200.

4. $\quad$ Ching, F.P., Omogbai, E.K.I., Ozolua, R.I., Okpo, S.O. (2008). Antidiarrhoeal activities of aqueous extract of Stereospermum kunthianum (Cham, Sandrine Petit) stem bark in rodents. African J. of Biotech. 7(9): 1220 - 1225. 
5. Ching, F.P., Okpo, S.O., Falodun, A., Omogbai, E.K.I. (2009). Antidiarrhoeal Activity of Chromatographic fractions of Stereospermum kunthianum, Cham Sandrine Petit (Bignoniaceae) stem Bark. Trop .J. Pharm. Res. 8(6): 515-519.

6. $\quad$ Ching, F.P., Falodun, A., Omogbai, E.K.I., Okpo, S.O., Ozolua, R.I., Iqbal, M. Choudhary (2009). Evaluation of analgesic and antiinflammatory compounds from Stereospermum kunthianum (Bignoniaceae). Int. J. Pharm. Tech. Res. 1(4): $1065-1068$.

7. Ching, F.P., Falodun, A. (2011). Dimethoxyflavone, a flavonoid from Stereospermum kunthianum stem bark with analgesic and antiinflammatory activities. West Afr. J. Pharmacol. And Drug Res.; 27: 16 - 20.

8. Di Carlo, G., Autore, G., Izzo, A.A., Maibline, P., Mascolo, N., Viola, P., Diurno, M.V., Capasso, F. (1993). Inhibition of intestinal motility and secretions by flavonoids in mice and rats: structure activity relationships. J. Pharm. Pharmacol. 45: $1054-1059$.

9. Di Carlo, G., Mascolo, N., Angelo A., Izzo, A.A., Capasso, F. (1999). Flavonoids: Old and new aspect of a class of natural therapeutic drugs. Life sciences, 65(4): 337 - 353.

10. Eugene, B.C. (1997). The Pathophysiology of Diarrhoea and Constipation In: Gastrointestinal Pharmacology and Therapeutics $1^{\text {st }}$ ed. (eds: Gerald, F., Eugene, D.J. and Richard, W.M). Lippincott-Raven. Philadelphia, pp. 157 - 172.

11. Falodun, A., Qadir, I.M., Poh, C.F., Omoghai, E.K.I., Choudhary, M.I. (2009). Bioactive chemical constituent of Stereospermum kunthianum (Bignoniaceae). Res. J. of Phytochem. 3(2): 35 - 43.

12. Gill, L.S. (1992). Ethnomedicinal uses of plants in Nigeria. University of Benin press, Benin, Nigeria p. 223

13. Guerrant, R.L., Van Gilder T., Steiner, T.S., Theilman, M.N., Slutsker, L., Tauxe, R.V., Thomas, H., Patricia, M.G., DuPont, H., Bradley Seck, R., Philip, T., Marguerite, N., Irving, N., Barth Reller, L., Michael, T.O., Michael, L.B., Larry, K.P. (2001) Practice guidelines for the management of infectious diarrhoeal. Clin Infec Dis; 32(3): 331 - 351

14. Izzo, A.A., Nicoletti, M., Giannattasio, B., Capasso, F. (1992). Antidiarrhoeal activity of Terminalia seric a Burch ex. Dc extracts In: Capasso, F, Mascolo, N. (eds). Natural drugs and Digestive tract, Rome, EMSI, pp. 223 - 230.

15. Keith, A.S., John, L.W. (2012). Treatment of disorders of bowel motility and water flux; antiemetics; agents used for biliary and pancreatic disease In: Goodman and Gilman's The Pharmacological Basis of Therapeutics, $12^{\text {th }}$ ed (Eds: Laurence LB and Bjorn CK) McGraw Hill, New York; pp. 1323 - 1366.

16. Kosek, M., Bern, C., Guerrant, R.R. (2003). The global burden of diarrhoeal disease, as estimated from studies published between 1992 and 2000. Bull World Health Organ. 81(3):197 - 204

17. National Institute of Health Guide for Care and Use of Laboratory Animals - NIH (1985). Principles of laboratory animal care. Pub No. 85 p. 23

18. Rajabhau, S.S., Biradar, K.V., Chiude, B.V., Shambhulingayya, H.M., Goud, V. (2011). In-vivo antidiarrhoeal activity of ethanolic extract of Delonix regia flowers in experimental induced diarrhoea in Wistar Albino Rats. Int. J. Research in Pharmacy and Chemistry: 1(3): $442-446$

19. Robert, A., Nezamis, J.E., Lancaster, C., Hanchar, A.L., Kleppre, M.S. (1976). Enteropooling assay: a test for diarrhoea produced by prostaglandins. Prostaglandins. 11: 809 - 814

20. Venkatesan. N., Thiyaganajan, V., Nanayanan, S., Arul, A., Raja, S., Gurusamy, S.V.K., Rajarajan, T., Perianayagam, J.B. (2005). Anti-diarrhoeal potential of asparagus racemosus wild root extracts in laboratory animals. J. Pharm Pharm. Sci; 8(1): 39 - 46.

21. Von Maydell, H.J (1986). Trees and shrubs of the sahel - their characteristics and uses. GTZ 6MBH; p. 286.

22. World Health Organization (WHO, 2009). Diarrhoeal disease Fact Sheet N0 330. 